\title{
Keefektifan Konseling Behavioral Teknik Modeling dan Konseling Analisis Transaksional Teknik Role Playing untuk Meminimalkan Kecenderungan Perilaku Agresif Siswa Sekolah Menengah Atas
}

\author{
I Ketut Gading, Umrotun Nisa, Luh Putu Sri Lestari \\ Jurusan Bimbingan dan Konseling, Fakultas Ilmu Pendidikan, Universitas Pendidikan Ganesha, \\ Jl. Udayana No. 11, Buleleng, Bali, Indonesia 81116 \\ E-mail: ketutgading35@gmail.com
}

Artikel diterima: 25 Agustus 2017; direvisi 30 Oktober 2017; disetujui 7 November 2017

\begin{abstract}
This study aims to determine the effectiveness of behavioral counseling using modeling technique and counseling transactional analysis using role playing technique to minimize student's tendency of aggressive behavior. This experimental research with pretestposttest control group design is taking samples using purposive sampling technique. The sample were 18 tenth grade students from Senior High School Laboratorium Universitas Pendidikan Ganesha who have high aggressive behavior. 18 sample were randomly assigned to three group, that is: (1) experimental group of behavioral counseling using modeling technique; (2) counseling transactional analysis using role playing technique group; and (3) control group. Data on aggressive behavior tendency before and after treatment were collected using questionnaire of aggressive behavior, then analyzed by $t$ test. The results show: (1) behavioral counseling using modeling technique were effective to minimize the tendency of aggressive behavior; (2) counseling transactional analysis using role playing technique were effective to minimize the aggressive behavior; and (3) counseling transactional analysis using role playing technique were more effectively minimizes the tendency of aggressive behavior rather than behavioral counseling using modeling technique.
\end{abstract}

Keywords: behavioral counseling; modeling; transactional analysis counseling; role playing; aggressive

\begin{abstract}
Abstrak: Penelitian ini bertujuan untuk mengetahui keefektifan konseling behavioral teknik modeling dan konseling analisis transaksional teknik role playing untuk meminimalkan kecenderungan perilaku agresif siswa. Penelitian eksperimen dengan rancangan pretestposttest control group design ini mengambil sampel dengan teknik purposive sampling. Sampel terdiri dari 18 orang siswa kelas X Sekolah Menengah Atas (SMA) Laboratorium Universitas Pendidikan Ganesha yang memiliki perilaku agresif tinggi. 18 sampel dibagi secara acak dan merata pada tiga kelompok, yaitu: (1) kelompok eksperimen yang mendapatkan perlakuan konseling behavioral teknik modeling; (2) kelompok eksperimen yang mendapatkan perlakuan konseling analisis transaksional teknik role playing; (3) dan kelompok kontrol. Data kecenderungan perilaku agresif sebelum dan sesudah perlakuan dikumpulkan dengan kuesioner perilaku agresif, kemudian dianalisis dengan uji t. Hasil menunjukkan: (1) konseling behavioral teknik modeling efektif meminimalkan kecenderungan perilaku agresif; (2) konseling analisis transaksional teknik role playing efektif meminimalkan perilaku agresif; dan (3) konseling analisis transaksional dengan teknik role playing lebih efektif meminimalkan kecenderungan perilaku agresif dibanding konseling behavioral teknik modeling.
\end{abstract}

Kata kunci: konseling behavioral; modeling; konseling analisis transaksional; role playing; agresif 
Hampir setiap hari media massa memberitakan fenomena perilaku agresif di masyarakat. Penghinaan terhadap oknum tertentu, perampokan, pemerkosaan, perkelahian, sampai bom bunuh diri, merupakan sejumlah perilaku agresif yang marak diberitakan belakangan ini. Kejadian-kejadian seperti itu tentu tidak dapat dibiarkan. Pengkajian yang mendalam dan penelitian yang sistematis dibutuhkan untuk menelusuri mengapa perilaku agresif itu marak terjadi, serta apa saja yang dapat dilakukan untuk mencegah atau menanggulanginya.

Perilaku agresif adalah perilaku yang ditujukan untuk menyakiti individu lain (Anderson \& Bushman, 2001) atau perilaku yang ditujukan untuk menimbulkan kerusakan, untuk menimbulkan kehancuran, serta untuk mengambil harta benda milik orang lain (Rahman, 2013). Baron \& Byrne, (1984) membedakan perilaku agresif menjadi 8 jenis yaitu: (1) perilaku agresif langsung-aktifverbal; (2) perilaku agresif tak langsung-aktif-verbal; (3) perilaku agresif langsung-pasif-verbal; (4) perilaku agresif tak langsung-pasif-verbal; (5) perilaku agresif lansung-aktif-nonverbal; (6) perilaku agresif tak langsung-aktif-nonverbal; (7) perilaku agresif langsung-pasif-nonverbal; dan (8) perilaku agresif tak langsung-pasif-nonverbal.

Menurut Freud, kecenderungan berperilaku agresif merupakan sifat bawaan yang berdiri sendiri dan juga merupakan tindakan instinktual manusia. Menurut teori psikoanalisa, energi agresif langsung dihasilkan oleh proses pertumbuhan. Perilaku agresif dihasilkan oleh desakan atau dorongan hati yang tersembunyi dan harus dilepaskan atau diekspresikan (Corey, 2015). Teori belajar sosial memandang perilaku agresi terjadi sebagai akibat seseorang mengamati dan meniru model yang melakukan perilaku agresif. Teori kognitif memandang bahwa cara mengolah dan menginterprestasi informasi tentang stimulus yang membangkitkan agresi di dalam pikiran akan memengaruhi perilaku agresif. Sementara teori behavioristik memandang perilaku agresif merupakan hasil belajar yang diperoleh dari lingkungan. Jika suatu saat individu melakukan perilaku agresif dan perilaku itu mendapatkan penguatan, maka perilaku agresif itu akan diulangi lagi di kemudian hari, sedangkan jika perilaku agresif itu tidak mendapatkan penguatan atau bahkan menghasilkan rasa sakit (punishment) maka perilaku tersebut akan cenderung dihindari di kemudian hari (Bensley \& Van Eenwyk, 2001).

Perilaku agresif dapat ditanggulangi dengan memanipulasi anteseden, yaitu dengan mengendalikan atau menjauhkan faktor-faktor penyebab terjadinya perilaku agresif. Manipulasi perilaku yaitu dengan mengarahkan perilaku untuk menghindari faktor-faktor penyebab perilaku agresif, dan manipulasi konsekuensi yaitu memberikan hadiah kepada individu ketika mampu menghindari perilaku agresif dan memberikan hukuman kepada individu ketika melakukan perilaku agresif (Calhoun \& Acocella, 1995). Selain itu, perilaku agresif juga dapat dicegah atau ditanggulangi dengan melakukan intervensi secara sengaja berupa terapi, konseling, atau pelatihan (Gading, 2014). Bimbingan kelompok juga terbukti efektif untuk mengurangi perilaku agresif verbal siswa (Winarlin, Lasan, \& Widada, 2016)

Beberapa penelitian menunjukkan bahwa konseling efektif untuk menanggulangi perilaku agresif atau meningkatkan perilaku yang menyebabkan perilaku agresif berkurang antara lain: konseling behavioral dengan teknik modeling efektif mengatasi perilaku agresif peserta didik kelas VIII SMP Negeri 07 Bandar Lampung (Damayanti \& Aeni, 2016). Penerapan konseling behavioral dengan teknik modeling juga efektif untuk meminimalkan perilaku agresif siswa kelas XI Bahasa SMA Negeri 2 Singaraja (Wiladantika, Dharsana, \& Suranata, 2014). Konseling analisis transaksional dengan teknik bermain peran juga efektif untuk meningkatkan afiliasi diri siswa kelas X SMK Negeri 1 Seririt tahun 2014/2015 (Agustini, Suarni, \& Putri, 2015).

Konseling behavioral teknik modeling adalah konseling untuk mengubah perilaku konseli yang didasarkan pada pandangan bahwa semua pengalaman yang didapat dari hasil belajar dapat dilakukan dengan cara melakukan pengamatan secara langsung atau tidak langsung kepada objek berikut konsekuensinya. Kecakapan-kecakapan sosial tertentu bisa diperoleh dengan mengamati dan mencontoh tingkah laku model-model yang ada. Reaksi-reaksi emosional yang terganggu milik seseorang juga bisa dihapus dengan cara orang tersebut mengamati orang lain yang mendekati objekobjek atau situasi-situasi yang ditakuti tanpa mengalami akibat-akibat yang menakutkan dengan tindakan yang dilakukannya (Bandura dalam Corey, 2015). Konseling Behavioral dengan teknik 
modeling dilakukan dengan langkah-langkah: (1) menetapkan bentuk model apakah model simbolik, model riil, atau model majemuk; (2) menetapkan skenario penampilan model; (3) menampilkan model disertai pengamatan perilaku spesifik yang hendak ditiru oleh konseli; (4) memotivasi konseli untuk melakukan peniruan terhadap perilaku model; (5) peniruan perilaku model oleh konseli dan menerapkan dalam kehidupan sehari-hari konseli; (6) evaluasi; dan (7) tindak lanjut.

Konseling analisis transaksional berakar pada filosofi anti deterministik dan menegaskan bahwa manusia mampu menyadari kondisi yang melatarbelakangi keputusan yang telah diambil di masa lalu. Analisis transaksional juga mengakui bahwa keputusan di masa lalu sangat bergantung pada orang lain, terutama pada orang-orang yang dipandang penting (significant others) dalam hidup mereka. Keputusan di masa lalu tersebut dapat ditinjau kembali dan ditantang, serta dibuat keputusan baru, apabila keputusan yang telah diambil tersebut tidak lagi cocok (Corey, 2015). Analisis transaksional membedakan perilaku manusia atau status ego menjadi tiga bagian yaitu ego orang tua, ego orang dewasa, dan ego anak-anak. Artinya dalam berkomunikasi dengan orang lain, tiap manusia memerankan salah satu dari tiga ego tersebut. Salah satu teknik konseling analisis transaksional adalah teknik bermain peran (role playing). Dalam konseling kelompok dengan teknik bermain peran, konseli dapat belajar cara berpikir dan berperilaku baru dari anggota kelompok yang lain (Corey, 2015). Konseli juga dapat merasakan atau mengidentifikasi dirinya seperti tokoh yang diperankan dalam permainan itu.

Sampai saat ini, belum ditemukan penelitian yang secara langsung menguji perbedaan keefektifan konseling behavioral teknik modeling dan konseling analisis transaksional teknik role playing dalam menurunkan perilaku agresif siswa, oleh karena itu penelitian ini bertujuan untuk menjawab tiga permasalahan pokok: (1) apakah konseling behavioral teknik modeling efektif untuk meminimalkan kecenderungan berperilaku agresif; (2) apakah konseling analisis transaksional teknik role playing efektif untuk meminimalkan kecenderungan berperilaku agresif; dan (3) apakah ada perbedaan keefektifan antara konseling behavioral teknik modeling dan konseling analisis transaksional teknik role playing dalam meminimalkan kecenderungan perilaku agresif.

\section{METODE}

Penelitian ini merupakan penelitian eksperimen semu (quasi-experiments) dengan rancangan "pretest-posttest control group design". Populasi dalam penelitian ini adalah siswa kelas X 4 dan X 5 SMA Laboratorium Universitas Pendidikan Ganesha di Singaraja yang berjumlah 55 orang. Pengambilan sampel menggunakan teknik purposive sampling yaitu siswa yang dijadikan sampel hanyalah siswa-siswa yang teridentifikasi memiliki kecenderungan perilaku agresif tinggi. Siswa diidentifikasi memiliki kecenderungan berperilaku agresif tinggi jika skor kuesioner pengukuran perilaku agresif berada pada rentang dua standar deviasi (2 SD) di atas angka rata-rata (M). Jumlah anggota sampel yang sebanyak delapan belas orang siswa, dibagi secara merata pada tiga kelompok. 6 orang ditugaskan secara acak menjadi anggota kelompok eksperimen satu yang mendapatkan perlakuan konseling behavioral teknik modeling, 6 orang masuk anggota kelompok eksperimen dua yang mendapatkan perlakuan konseling analisis transaksional teknik role playing, dan 6 orang lagi sebagai anggota kelompok kontrol.

Prosedur penelitian diawali dengan melaksanakan pretest dengan menyebarkan kuesioner kecenderungan perilaku agresif kepada ketiga kelompok. Setelah pretest dilaksanakan, dilanjutkan dengan memberikan perlakuan berupa konseling behavioral teknik modeling kepada kelompok eksperimen satu sebanyak delapan kali dalam bentuk konseling kelompok. Kelompok eksperimen dua diberikan perlakuan berupa konseling analisis transaksional dengan teknik role playing juga sebanyak delapan kali pertemuan dalam bentuk konseling kelompok, sedangkan kelompok kontrol tidak diberi perlakuan. Dalam konseling behavioral teknik modeling, para siswa kelompok eksperimen satu diajak menyaksikan model dalam film yang berperilaku agresif dan mendapatkan risiko tidak menyenangkan, serta menyaksikan model dalam film yang mampu menahan diri untuk tidak berperilaku agresif dan mendapatkan risiko yang menyenangkan. Setiap selesai menonton 
film, para siswa diajak berdiskusi untuk melaporkan dan membahas perilaku tokoh yang disaksikan. Dalam kelompok eksperimen dua yang diberi konseling analisis transaksional teknik role playing, siswa diajak bermain peran dengan skenario cerita seorang siswa berperilaku agresif dan mendapatkan risiko yang tidak menyenangkan serta skenario cerita seorang siswa mampu menahan diri untuk tidak berperilaku agresif dan mendapatkan risiko yang menyenangkan. Setelah kelompok eksperimen satu dan dua mendapatkan perlakuan, penelitian dilanjutkan dengan melaksanakan posttest dengan menyebarkan kuesioner kecenderungan perilaku agresif kepada kelompok eksperimen satu, kelompok eksperimen dua, dan kelompok kontrol.

Variabel penelitian ini terdiri dari konseling behavioral teknik modeling dan konseling analisis transaksional teknik role playing sebagai variabel bebas, dan kecenderungan perilaku agresif sebagai variabel terikat. Data tentang kecenderungan perilaku agresif dalam penelitian ini dikumpulkan dengan kuesioner kecenderungan perilaku agresif yang telah teruji validitas isinya, validitas butirnya, dan reliabilitas perangkatnya. Untuk menguji hipotesis, data dianalisis dengan menggunakan uji t dengan terlebih dahulu dilakukan uji prasyarat analisis berupa uji normalitas sebaran data dengan menggunakan teknik Kolmogorov-Smirnov, dan uji homogenitas varian dengan menggunakan teknik Levene's Test.

\section{HASIL}

\section{Deskripsi Data}

Deskripsi data pretest dan posttest pada masing-masing kelompok ditampilkan dalam tabel 1. Tabel 1 menunjukkan bahwa terjadi penurunan skor rata-rata perilaku agresif dari sebelum perlakuan ke setelah perlakuan, baik pada kelompok eksperimen satu, kelompok eksperimen dua, maupun kelompok kontrol.

\section{Hasil Uji Hipotesis 1}

Hipotesis satu menyatakan bahwa konseling behavioral teknik modeling efektif untuk meminimalkan perilaku agresif. Ringkasan hasil uji hipotesis dengan uji t berbantuan program SPSS disajikan pada tabel 2. Tabel 2 menunjukkan bahwa nilai t yang diperoleh sebesar 11,504 dengan signifikansi sebesar 0,000 . Nilai signifikansi tersebut mengandung arti bahwa nilai t yang diperoleh signifikan. Ini berarti hipotesis yang menyatakan konseling behavioral teknik modeling efektif untuk meminimalkan perilaku agresif teruji secara empiris.

Tabel 1 Deskripsi Data Kecenderungan Perilaku Agresif Pretest dan Posttest

\begin{tabular}{lcccccc}
\hline & \multicolumn{2}{c}{$\begin{array}{c}\text { Kelompok } \\
\text { Eksperimen 1 }\end{array}$} & \multicolumn{2}{c}{$\begin{array}{c}\text { Kelompok } \\
\text { Eksperimen 2 }\end{array}$} & \multicolumn{2}{c}{$\begin{array}{c}\text { Kelompok } \\
\text { Kontrol }\end{array}$} \\
\hline No & $\begin{array}{c}\text { Skor } \\
\text { Pretest }\end{array}$ & $\begin{array}{c}\text { Skor } \\
\text { Posttest }\end{array}$ & $\begin{array}{c}\text { Skor } \\
\text { Pretest }\end{array}$ & $\begin{array}{c}\text { Skor } \\
\text { Posttest }\end{array}$ & $\begin{array}{c}\text { Skor } \\
\text { Pretest }\end{array}$ & $\begin{array}{c}\text { Skor } \\
\text { Posttest }\end{array}$ \\
\hline 1 & 135 & 111 & 136 & 96 & 131 & 106 \\
\hline 2 & 134 & 96 & 133 & 86 & 148 & 120 \\
\hline 3 & 134 & 108 & 138 & 94 & 146 & 122 \\
\hline 4 & 136 & 100 & 134 & 88 & 143 & 111 \\
\hline 5 & 135 & 111 & 134 & 108 & 140 & 118 \\
\hline 6 & 134 & 107 & 133 & 90 & 136 & 107 \\
\hline$\sum$ & 808 & 633 & 808 & 562 & 864 & 684 \\
\hline Rerata & 134,7 & 105,5 & 134,7 & 93,7 & 144 & 114 \\
\hline Minimum & 134 & 96 & 133 & 86 & 131 & 106 \\
\hline Maksimum & 136 & 111 & 138 & 108 & 148 & 122 \\
\hline $\begin{array}{l}\text { Std. } \\
\text { Deviation }\end{array}$ & 0,82 & 6,16 & 1,97 & 7,94 & 6,38 & 6,90 \\
\hline & & & & & & \\
\hline
\end{tabular}


Tabel 2 Ringkasan Hasil Uji t untuk Uji Hipotesis 1

\begin{tabular}{|c|c|c|c|c|c|c|c|c|c|c|}
\hline \multicolumn{11}{|c|}{ Independent Samples Test } \\
\hline & & \multicolumn{2}{|c|}{$\begin{array}{c}\text { Levene's Test } \\
\text { for Equality of } \\
\text { Variances }\end{array}$} & \multicolumn{7}{|c|}{ t test for Equality of Means } \\
\hline & & \multirow[t]{2}{*}{$\mathbf{F}$} & \multirow[t]{2}{*}{ Sig. } & \multirow[t]{2}{*}{$\mathbf{t}$} & \multirow[t]{2}{*}{ Df } & \multirow[t]{2}{*}{$\begin{array}{c}\text { Sig. } \\
\text { (2-tailed) }\end{array}$} & \multirow[t]{2}{*}{$\begin{array}{c}\text { Mean } \\
\text { Difference }\end{array}$} & \multirow[t]{2}{*}{$\begin{array}{l}\text { Std. Error } \\
\text { Difference }\end{array}$} & \multicolumn{2}{|c|}{$\begin{array}{l}\text { 95\% Confidence } \\
\text { Interval of the } \\
\text { Difference }\end{array}$} \\
\hline & & & & & & & & & Lower & Upper \\
\hline \multirow{2}{*}{$\begin{array}{l}\text { Kecen- } \\
\text { derungan } \\
\text { Perilaku } \\
\text { Agresif }\end{array}$} & $\begin{array}{l}\text { Equal } \\
\text { variances } \\
\text { assumed }\end{array}$ & 14.025 & .004 & 11.504 & 10 & .000 & 29.167 & 2.535 & 23.518 & 34.816 \\
\hline & $\begin{array}{l}\text { Equal } \\
\text { variances } \\
\text { not } \\
\text { assumed }\end{array}$ & & & 11.504 & 5.176 & .000 & 29.167 & 2.535 & 22.715 & 35.618 \\
\hline
\end{tabular}

Tabel 3 Ringkasan Hasil Uji t untuk Uji Hipotesis 2

\begin{tabular}{|c|c|c|c|c|c|c|c|c|c|c|}
\hline & & $\begin{array}{c}\text { Leven } \\
\text { for Eq } \\
\text { Vari }\end{array}$ & $\begin{array}{l}\text { Test } \\
\text { lity of } \\
\text { ces }\end{array}$ & & & t test & for Equality & of Means & & \\
\hline & & $\mathbf{F}$ & Sig. & $\mathbf{t}$ & Df & $\underset{\text { (2-tailed) }}{\text { Sig. }}$ & $\begin{array}{c}\text { Mean } \\
\text { Difference }\end{array}$ & $\begin{array}{l}\text { Std. Error } \\
\text { Difference }\end{array}$ & $\begin{array}{r}95 \% \text { Co } \\
\text { Interva } \\
\text { Diffe }\end{array}$ & $\begin{array}{l}\text { nfidence } \\
\text { l of the } \\
\text { rence }\end{array}$ \\
\hline & & & & & & & & & Lower & Upper \\
\hline $\begin{array}{l}\text { Kecen- } \\
\text { derungan } \\
\text { Perilaku } \\
\text { Agresif }\end{array}$ & $\begin{array}{l}\text { Equal } \\
\text { variances } \\
\text { assumed }\end{array}$ & 8.812 & .014 & 9.845 & 10 & .000 & 38.167 & 3.877 & 29.529 & 46.804 \\
\hline
\end{tabular}

Tabel 4 Ringkasan Hasil Uji t untuk Uji Hipotesis 3

\begin{tabular}{|c|c|c|c|c|c|c|c|c|c|c|}
\hline \multicolumn{11}{|c|}{ Independent Samples Test } \\
\hline & & $\begin{array}{r}\text { Leve } \\
\text { Test } \\
\text { Equa } \\
\text { Varic }\end{array}$ & $\begin{array}{l}\text { ne's } \\
\text { for } \\
\text { ity of } \\
\text { nces }\end{array}$ & \multicolumn{7}{|c|}{ t test for Equality of Means } \\
\hline & & \multirow[t]{2}{*}{$\mathbf{F}$} & \multirow[t]{2}{*}{ Sig. } & \multirow[t]{2}{*}{$\mathbf{t}$} & \multirow[t]{2}{*}{ Df } & \multirow[t]{2}{*}{$\underset{(2-t a i l e d)}{\text { Sig. }}$} & \multirow[t]{2}{*}{$\begin{array}{c}\text { Mean } \\
\text { Difference }\end{array}$} & \multirow[t]{2}{*}{$\begin{array}{l}\text { Std. Error } \\
\text { Difference }\end{array}$} & \multicolumn{2}{|c|}{$\begin{array}{l}\text { 95\% Confidence } \\
\text { Interval of the } \\
\text { Difference }\end{array}$} \\
\hline & & & & & & & & & Lower & Upper \\
\hline \multirow[t]{2}{*}{$\begin{array}{l}\text { Kecen- } \\
\text { derungan } \\
\text { Perilaku } \\
\text { Agresif }\end{array}$} & $\begin{array}{l}\text { Equal } \\
\text { variances } \\
\text { assumed }\end{array}$ & .074 & .792 & -2.708 & 10 & .022 & -.85667 & .31638 & -1.56160 & .15173 \\
\hline & $\begin{array}{l}\text { Equal } \\
\text { variances } \\
\text { not } \\
\text { assumed }\end{array}$ & & & -2.708 & 8.910 & .024 & -.85667 & .31638 & -1.57347 & .13987 \\
\hline
\end{tabular}

\section{Hasil Uji Hipotesis 2}

Hipotesis dua menyatakan konseling analisis transaksional teknik role playing efektif untuk meminimalkan perilaku agresif. Ringkasan hasil uji t untuk menguji hipotesis dua disajikan pada tabel 3. Tabel 3 menunjukkan bahwa koefisien nilai $t$ yang diperoleh sebesar 9,845 dengan taraf signifikansi sebesar 0,000 . Signifikansi nilai $\mathrm{t}$ tersebut menandakan nilai $\mathrm{t}$ hasil perhitungan signifikan. Ini berarti hipotesis dua yang menyatakan konseling analisis transaksional teknik role playing efektif meminimalkan kecenderungan perilaku agresif teruji secara empirik. 


\section{Hasil Uji Hipotesis 3}

Hipotesis tiga menyatakan ada perbedaan keefektifan antara konseling behavioral teknik modeling dengan konseling analisis transaksional teknik role playing dalam meminimalkan kecenderungan perilaku agresif. Ringkasan hasil uji $t$ untuk menguji hipotesis tersebut disajikan pada tabel 4. Tabel 4 menunjukkan bahwa nilai t hitung yang diperoleh sebesar $-2,708$ dengan taraf signifikansi 0,022 . Taraf signifikansi tersebut menunjukkan bahwa nilai t hasil perhitungan signifikan. Ini berarti hipotesis tiga dalam penelitian ini yang menyatakan ada perbedaan keefektifan antara konseling behavioral teknik modeling dengan konseling analisis transaksional teknik role playing teruji secara empirik, dan konseling analisis transaksional dengan teknik role playing lebih efektif daripada konseling behavioral teknik modeling.

\section{PEMBAHASAN}

\section{Konseling Behavioral dengan Teknik Modeling dan Kecenderungan Perilaku Agresif}

Hasil pertama dari penelitian ini adalah bahwa konseling behavioral teknik modeling efektif untuk meminimalkan kecenderungan perilaku agresif. Hasil penelitian ini membuktikan bahwa perilaku baru dapat dipelajari dan dihapuskan dengan mengamati dan meniru perilaku tokoh atau model (Bandura, 1977). Tayangan kekerasan di televisi, film, permainan video, telepon seluler, dan internet dapat meningkatkan risiko perilaku kekerasan bagi pemirsa (Huesmann, 2007). Temuan ini juga mengandung arti tayangan-tayangan perilaku tokoh yang mengendalikan diri untuk tidak berperilaku agresif di televisi, film, dan media sosial lainnya juga berpengaruh terhadap menurunnya kecenderungan perilaku agresif pemirsanya. Sekali lagi, kesimpulan ini sesuai dengan pandangan para pakar psikologi behavioristik, bahwa cara perilaku dipelajari sama dengan cara perilaku itu dihapuskan. Perilaku agresif orang tua juga memengaruhi perilaku agresif anak terhadap teman sebayanya (Anderson \& Bushman, 2001). Temuan ini mengandung arti bahwa anak mempelajari perilaku dari model terdekat (orang tua). Sesungguhnya tidak hanya perilaku agresif yang dipelajari individu dari model, tetapi juga perilaku tidak agresif.

Hasil penelitian ini relevan dengan hasil-hasil penelitian terdahulu, yang menyebutkan bahwa konseling behavioral teknik modeling efektif mengatasi perilaku agresif peserta didik kelas VIII SMP Negeri 07 Bandar Lampung (Damayanti \& Aeni, 2016). Penerapan konseling behavioral dengan teknik modeling juga efektif untuk meminimalkan perilaku agresif siswa kelas XI Bahasa SMA Negeri 2 Singaraja (Wiladantika dkk., 2014)

\section{Konseling Analisis Transaksional teknik Role Playing dan Kecenderungan Perilaku Agresif}

Temuan kedua dari penelitian ini adalah bahwa konseling analisis transaksional teknik role playing efektif meminimalkan kecenderungan perilaku agresif. Temuan penelitian ini membuktikan secara empiris bahwa mengubah perilaku seseorang dapat dilakukan dengan bermain peran, misalnya dalam sebuah sosiodrama. Hal ini dapat terjadi karena dengan bermain peran, individu merefleksi perilakunya, mendapatkan tantangan dari teman bermain, dan menimbulkan niat untuk melakukan perubahan (Corey, 2015). Hasil penelitian ini relevan dengan hasil penelitian terdahulu, yang menemukan bahwa konseling analisis transaksional dengan teknik bermain peran efektif untuk meningkatkan afiliasi diri siswa Kelas X SMK Negeri 1 Seririt tahun 2014/2015 (Agustini dkk., 2015).

\section{Konseling Behavioral Teknik Modeling, Konseling Analisis Transaksional Teknik Role Playing dan Kecenderungan Perilaku Agresif}

Temuan ketiga dari penelitian ini adalah bahwa konseling analisis transaksional teknik role playing lebih efektif daripada konseling behavioral teknik modeling dalam meminimalkan kecenderungan perilaku agresif. Temuan ini sangat mungkin terjadi karena dalam konseling analisis transaksional teknik role playing, konseli mendapatkan pengalaman berperan, menghayati, dan mempraktikkan 
perilaku tertentu dalam bermain peran, kemudian mendapatkan masukan atau tantangan dari teman bermain lainnya. Pengalaman ini nampaknya membuat konseli lebih besar niatnya untuk mengekang dirinya dari berperilaku agresif bilamana ada kondisi yang menstimulasi untuk berperilaku agresif. Berbeda halnya dalam konseling behavioral teknik modeling. Dalam konseling ini konseli hanya menyaksikan perilaku model yang hendak ditiru, tanpa mendapatkan kesempatan mempraktikkan perilaku itu dalam latar konseling. Keadaan seperti itulah yang amat mungkin menyebabkan konseling analisis transaksional teknik role playing lebih efektif meminimalkan kecenderungan perilaku agresif siswa SMA.

Temuan penelitian lain yang secara langsung menguji perbedaan keefektifan konseling behavioral teknik modeling dan konseling analisis transaksional teknik role playing sampai saat ini belum ditemukan. Hasil-hasil penelitian tentang kuatnya pengaruh konseling analisis transaksional terhadap perubahan perilaku, antara lain: konseling analisis transaksional dengan teknik role playing mampu menurunkan persentase perilaku agresif dari 80\% menjadi $45 \%$ dalam dua siklus penelitian tindakan kelas (Maepin, Suarni, \& Mudjijono, 2013); konseling analisis transaksional berpengaruh terhadap keterampilan berkomunikasi interpersonal peserta didik kelas VIII SMP Negeri 18 Bandar Lampung tahun pelajaran 2015/2016 (Handayani, 2016).

\section{SIMPULAN}

Berdasarkan hasil penelitian dan pembahasan dapat disimpulkan bahwa: (1) konseling behavioral teknik modeling maupun konseling analisis transaksional teknik role playing samasama efektif meminimalkan kecenderungan perilaku agresif siswa SMA; (2) konseling analisis transaksional teknik role playing lebih efektif daripada konseling behavioral teknik modeling dalam meminimalkan kecenderungan perilaku agresif siswa SMA. Demikian semakin dapat diyakini bahwa konseling, khususnya konseling behavioral teknik modeling dan konseling analisis transaksional teknik role playing efektif untuk meminimalkan kecenderungan perilaku agresif siswa SMA.

Saran terkait simpulan adalah agar Guru Bimbingan dan Konseling menggunakan konseling, khususnya konseling analisis transaksional teknik role playing atau konseling behavioral teknik modeling untuk mencegah atau menanggulangi perilaku agresif siswa SMA.

\section{DAFTAR RUJUKAN}

Agustini, L. P. D., Suarni, N. K., \& Putri, D. A. W. M. (2015). Pengaruh Konseling Analisis Transaksional dengan Teknik Bermain Peran untuk Meningkatkan Afiliasi Siswa Kelas X AP1 SMK Negeri 1 Seririt Tahun 2014/2015. Jurnal Ilmiah Bimbingan Konseling, 3(1).

Anderson, C. A., \& Bushman, B. J. (2001). Effects of Violent Video Games on Aggressive Behavior, Aggressive Cognition, Aggressive Affect, Physiological Arousal, and Prosocial Behavior: A Meta-Analytic Review of The Scientific Literature. Psychological Science, 12(5), 353-359.

Bandura, A. (1977). Self-efficacy: Toward a Unifying Theory of Behavioral Change. Psychological Review, 84(2), 191.

Baron, R. A., \& Byrne, D. E. (1984). Social Psychology: Understanding Human Interaction. Allyn \& Bacon.

Bensley, L., \& Van Eenwyk, J. (2001). Video Games and Real-life Aggression: Review of The Literature. Journal of Adolescent Health, 29(4), 244-257.

Calhoun, J. F., \& Acocella, J. R. (1995). Psikologi Tentang Penyesuaian dan Hubungan Kemanusiaan. Semarang: IKIP Semarang.

Corey, G. (2015). Theory and Practice of Counseling and Psychotherapy. Book, Nelson Education.

Damayanti, R., \& Aeni, T. (2016). Efektivitas Konseling Behavioral dengan Teknik Modeling untuk Mengatasi Perilaku Agresif pada Peserta Didik Kelas VIII B SMP Negeri 07 Bandar Lampung. KONSELI: Jurnal Bimbingan dan Konseling (E-Journal), 3(1), 1-10. 
Gading, I. K. (2014). Keefektifan Pelatihan Kendali Diri untuk Mencegah dan Menanggulangi Perilaku Prokrastinasi Akademik. Singaraja: Universitas Pendidikan Ganesha

Handayani, M. (2016). Pengaruh Layanan Konseling Kelompok Pendekatan Analisis Transaksional terhadap Keterampilan Komunikasi Peserta Didik Kelas VIII SMP Negeri 18 Bandar Lampung Tahun Pelajaran 2015/2016. (Skripsi tidak diterbitkan). Institut Agama Islam Negeri Raden Intan.

Huesmann, L. R. (2007). The Impact of Electronic Media Violence: Scientific Theory and Research. Journal of Adolescent Health, 41(6), S6-S13.

Maepin, N. K., Suarni, N. K., \& Mudjijono, M. (2013). Penerapan Konseling Analisis Transaksional dengan Teknik Role Playing untuk Meminimalisasi Perilaku Bullying Siswa. Jurnal Ilmiah Bimbingan Konseling, 1(1).

Rahman, A. A. (2013). Psikologi Sosial: Integrasi Pengetahuan Wahyu dan Pengetahuan Empirik. Jakarta: PT. Raja Grafindo Persada.

Wiladantika, K. P., Dharsana, I. K., \& Suranata, K. (2014). Penerapan Konseling Behavioral dengan Teknik Modeling untuk Meminimalisir Perilaku Agresif Siswa Kelas XI Bahasa SMA Negeri 2 Singaraja. Jurnal Ilmiah Bimbingan Konseling, 2(1).

Winarlin, R., Lasan, B. B., \& Widada, W. (2016). Efektivitas Teknik Sosiodrama Melalui Bimbingan Kelompok untuk Mengurangi Perilaku Agresif Verbal Siswa SMP. Jurnal Kajian Bimbingan dan Konseling, 1(2), 68-73. http://dx.doi.org/10.17977/um001v1i22016p068

Artikel ini merupakan artikel terpilih dari Seminar dan Lokakarya Nasional Bimbingan dan Konseling 2017 (Malang, 4-6 Agustus 2017) yang telah melalui tahap review oleh Komite Seminar dan Lokakarya Nasional Bimbingan dan Konseling 2017 serta Mitra Bebestari Jurnal Kajian Bimbingan dan Konseling 